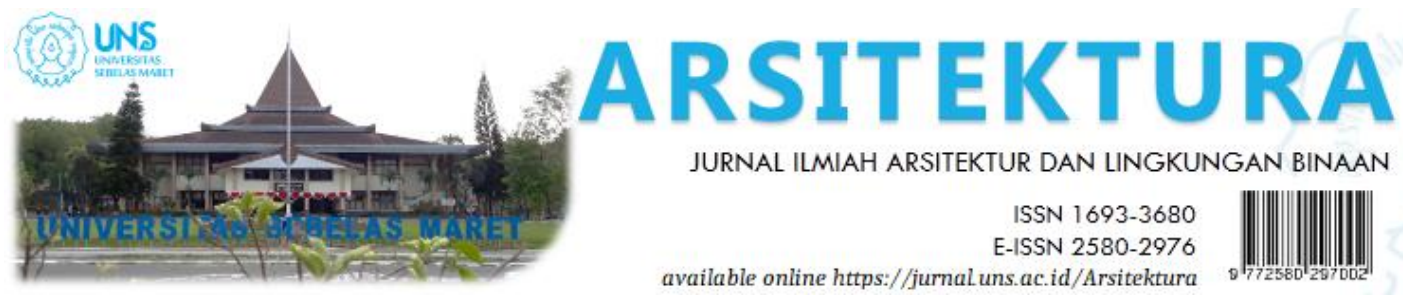

Volume 19 Issue 2 October 2021, pages:217-230

\title{
Nilai Kearifan Rumah Hijau (Greenship Homes) Permukiman Pedesaan Lereng Gunung, kasus Desa Kledung, Temanggung.
}

\section{Wisdom Value of Greenship homes in The Slope of Mountain Settlement, case on Kledung Village, Temanggung}

VG Sri Rejeki ${ }^{1 *}$, Romantio Veronika Ndruru ${ }^{2}$, Gita Cynthia Bella K. ${ }^{3}$, Zia Amalia Wafi ${ }^{4}$ Architecture Department, Faculty of Architecture and Design, Soegijapranata Chatolic University ${ }^{*}$ vege@unika.ac.id; srejeki.aja@gmail.com

Architecture Department, Faculty of Architecture and Design, Soegijapranata Chatolic University ${ }^{2}$ Architecture Department, Faculty of Architecture and Design, Soegijapranata Chatolic University ${ }^{3}$ Architecture Master's Department, Faculty of Architecture and Design, Soegijapranata Chatolic University ${ }^{4}$

DOI: https://doi.org/10.20961/arst.v19i2.49723

Received: March 21,2021 Revised: July 22,2021 Accepted: July 28,2021 Available online: October 30,2021

\begin{abstract}
The implementation of greenship homes rating tools on houses in residential areas has been carried out in recent times. On the other hand, in mountain settlements have the value of local wisdom considers the environment as the basis of settlement management. The purpose of this study found the value of green buildings mountain settlements, the case of Kledung Village, Wonosobo, using the analysis of greenship homes rating tools. Qualitative research is conducted by physical mapping methods and interviews to homeowner informants. The study used 12 purposive samples, which were defined based on four character locations. The results of the study, based on 4 character location of the case, greenship homes value is relatively similar/its same. There is no difference in value between one case than another, so that analysis is done at once. Overall, the results of the study explained that the greenship homes rating tool can be applied in kledung village. The result is 1) all buildings are larger than the ratio of greenship rating tools, 2) all houses have electricity meters and monitoring; 3) sorting of organic and inorganic waste; 4) pest management; 5) some houses use recicled, reuse, and local materials, 6) sunny utilization and solar entry into homes and cross-circulation wind management in houses. Uniquenesse's finding are 1) there is a minimum large tree in Kledung village, because the village has cold temperatures, high humidity and little daily sunlight time. In addition, the people in Kledung Village do not regulate clean water, because it is abundant in this village
\end{abstract}

Keywords: mountain settlement; greenship homes rating tools; local wisdom

\section{PENDAHULUAN}

Pada masa dewasa ini, pemikiran pembangunan berbasis bangunan hijau merupakan suatu keniscayaan yang harus dihadapi dan menjadi pertimbangan di dalam pengembangan tata lingkungan, permukiman perkotaan pada berbagai tempat dan situasi. Beberapa analisis memperlihatkan bahwa semua analisis dutujukan untuk bangunan di tengah kota, seperti disampaikan oleh Wahyu (2019) tentang bangunan hijau fungsi umum, kasus rumah susun oleh Latuconsina, (2018) maupun di daerah perumahan kota seperti dilakukan oleh Azizah (2017), Dianty (2018) Pambudi (2014). 
Terdapat beberapa cara pengukuran bangunan hijau di Indonesia, salah satunya adalah tolok ukur yang terdapat pada Green Building Council Indonesia (GBCI) rating tools. Pada awal penerapan rating tools GBCI, pengukuran diterapkan pada pangunan baru (new buildings ratting tools). Pada tahun 2014 penerapan pengukuran sudah diterapkan untuk bangunan baru, bangunan eksisting, interior, kompleks/ kawasan (neigbourhood rating tools) dan rumah hijau (greenship homes, GBCI 2014). Dalam telaah lebih lanjut, keberadaan alat-alat pengukuruan bangunan hijau diarahkan untuk bangunan di kota, yang memiliki permasalahan tinggi, seperti hasil telaah yang dilakukan pleh Pambudi (2014), Azizah (2017), Dianty (2018) dan Yanta (2019) tentang penilaian menggunakan rating tools pada perumahan pada beberapa kota di Indonesia, maupun penelitian Latuconsina untuk penerapan tolok ukur du rumah susun (bertingkat). Dengan adanya penekanan ini, kesan yang diperoleh seakan bangunan hijau yang menyikapi alam merupakan konsep yang baru ditemukan dan ditetapkan alat analisisnya.

Hal yang menarik penelitian ini adalah, adanya nilai bangunan maupun rumah hijau di daerah pedesaan, khususnya di pegunungan pada dasarnya memiliki kearifan lokal yang sangat peduli terhadap alam, terutama terkait mata pencaharian bertani, berkebun mapun berladang( Rejeki, 2010 dan Santosa, 2019), maupun kearifan penyesuaian kondisi alam (Rejeki 2015). Dalam hal ini Helmi (2014) juga menyampaikan bahwa kearifan lokal permukiman lereng gunung memiliki nilai ekologi tinggi, bahkan tingkat ekologi berdasar pada spiritual. Penelitian kali ini bertujuan untuk mengetahui apakah pada Permukiman pegunungan dengan kearifan lokalnya dapat dinilai menurut tolok pengukuran terprogram seperti tolok ukur menurut GBCI (greenship homes rating tools). Seperti pendapat Helmi (2014) yang menyampaikan kearifan lokal di desa lereng gunung pada dasarnya penuh nilai ekologi, didasari oleh nilau prisitual yang lebih tinggi dibanding dengan nilai lingkungan dan kesehatan seperti yang terdapat pada lokasilokasi lain.

Penelitian kasus di Desa Kledung, Temanggung lereng Gunung Sindoro dipilih dengan pertimbangan desa ini sebagai desa yang banyak didatangi oleh orang dari luar Kawasan dengan tujuan camping, naik gunung. Posisi Desa Kledung pada puncak pass antara Gunung Sindoro dan Gunung Sumbing (Gambar 1). Hal ini dapat menyebabkan desa akan mudah kehilangan kearifan lokal apabila tidak disikapi penyadaran kearifan sejak awal.

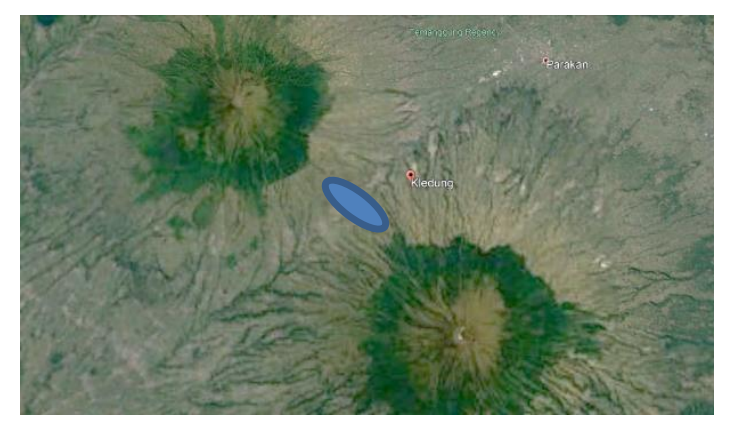

Gambar 1. Posisi Desa Kledung, Kecamatan Kledung, Temanggung

Sumber: Google Earth, diakses 12 Maret 2021.

Skala lebih mikro, Desa Kledung, Kecamatan Kledung terbelah oleh jalur jalan Temanggung Wonosobo, dengan kondisi dominasi permukiman ada di sisi atas (Utara) jalan (Gambar 02). Keberadaan Desa Kledung pada kawasan puncak pass, dengan sangat dimungkinkan masyarakat masih berpijak pada kearifan pengelolaan lingkungan sejalan dengan potensi alam yang ada, yaitu alam puncak pass daerah pegunungan (antara Gunung Sindoro dan Gunung Sumbing).

Sejalan dengan perkembangan proses pembangunan dan perkembangan kawasan mempertimbangkan bangunan hijau, maka dalam penelitian ini dilakukan kajian apakah nilai kearifan yang menyikapi alam yang sudah diterapkan secara natural sejak lama, apakah pada dasarnya sejalan dengan rumusan baru terkait dengan bangunan rumah hijau (greenship homes rating tools) yang baru ditetapkan oleh GBCI (2014).

Pengamatan dilakukan berdasar pada pertimbangan, dari seluruh tolok ukur yang ada menurut GBCI, disikapi sebagai unsur yang perlu diamati, sedangkan untuk melihat kedalaman, ditetapkan secara sederhana yaitu tentang keberadaan atau tidaknya. Hal ini dilihat baik tolok pengukutan yang bersifat prasyarat, maupun yang bersifat pendukung. 


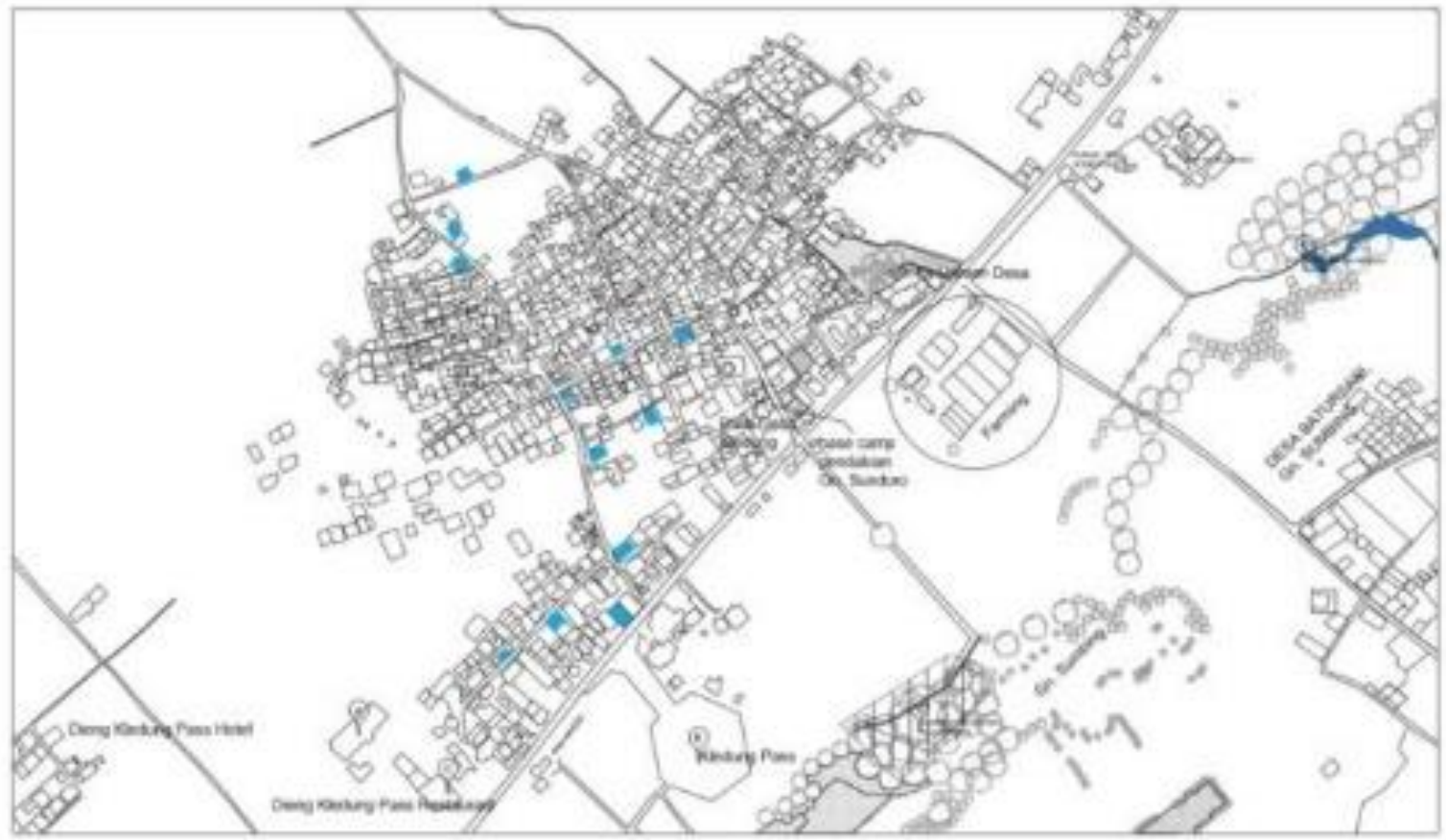

Gambar 2. Desa Kledung

Sumber: Digambar dari Google Earth, Mei 2020

Sesuai tolok ukur yang ada di GBCI (2014), yaitu bangunan dapat dikategorikan sebagai bangunan hijau antara lain menyangkut 1) Manajemen Lingkungan Bangunan, 2) Tepat Guna Lahan, 3) Konservasi Air , 4) Efisiensi dan konservasi energi, 5) Sumber dan daur ulang material dan 6) Keamanan dan kenyamanan dalam ruang (Gambar 3).

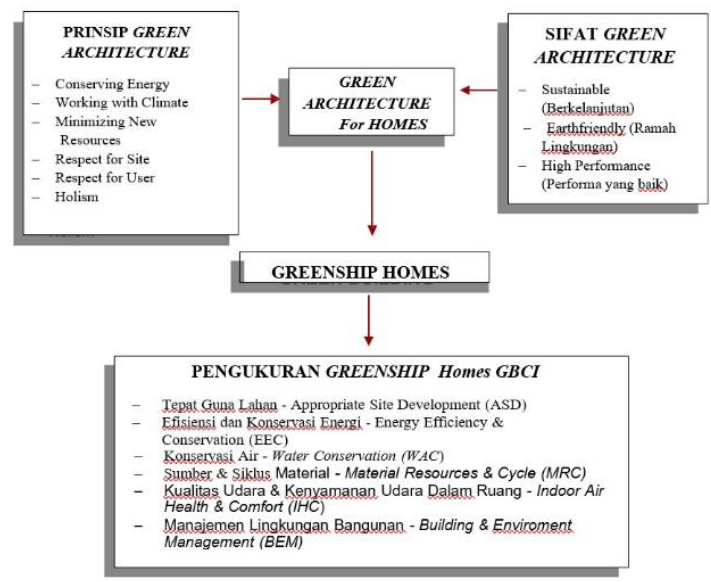

Gambar 3. Kerangka teoritik

Sumber: analisis berdasar GBCI, 2014

Dalam kajian yang dilakukan (GBCI, 2014), masing-masing tolok ukur memiliki persyaratan dan penentu nilai. Pada penelitian ini, kedua macam tolok ukur dilihat keberadaannya. Beberapa kriteria dan tolok ukur prasarat yang dicermati keberadaan/ penerapannya terdapat pada tabel 1 .

Tabel 1. Tolok ukur prasyarat

\begin{tabular}{llll}
\hline Uraian & \multicolumn{3}{c}{ Tolok Ukur } \\
\cline { 2 - 4 } & $\begin{array}{l}\text { Ada } \\
\text { besar } \\
\text { (nilai 3) }\end{array}$ & $\begin{array}{l}\text { Ada } \\
\text { sedikit } \\
\text { (nilai 2) }\end{array}$ & $\begin{array}{l}\text { Tidak } \\
\text { ada } \\
\text { (nilai }\end{array}$ \\
Kesesuaian & Murni & Mayoritas & Camp \\
fungsi & hunian & hunian & ur lain \\
Resapan/ KDH & Sesuai & Kurang & Tidak \\
& KDH & sesuai & ada \\
Meter listrik & ada & Ada tidak & Tidak \\
& berfungsi & berfungsi & ada \\
Pasif energi & Banyak & Sedikit & Tidak \\
& bukaan & bukaan & ada \\
& sinar & & bukaan \\
Pengurangan & Semua ada/ memenuhi, karena \\
Ozon & tidak ada yg menggunakan AC \\
material & Non & Ada & Ada \\
& asbestor & sedikit & banyak \\
Pengelolaan & Dipilah & Sedikit & Tidak \\
sampah & semua & dipilah & dipilah \\
\hline
\end{tabular}

Sumber: diolah dari Greenship homes GBCI

Selain analisis pada unsur prasyarat dari bangunan rumah hijau (greenship homes), juga dilakukan analisis terhadap unsur-unsur yang perlu menjadi perhatian di dalam menganalisis bangunan, yang dihargai menurut nilai-nilai rumah hijau secara umum. Secara gambaran 
awal, dimungkinkan dalam hal ini ada beberapa unsur penilaian yang tidak terdapat di desa Kledung, karena tidak dilakukan pada kawasan pegunungan. Salah satunya prasyarat adanya AC yang bebas polusi juga tidak ada, karena rumah di gunung tidak menggunakan AC.

Beberapa kriteria rumah hijau GBCI (2014) yang tidak dianalisis, karena dikategorikan memenuhi dengan keberadaan kasus rumah di daerah pegunungan (kategori ada/ memenuhi semua) antara lain:

- Tanpa penggunaan AC

- Pengurangan jejak karbon tidak diukur karena masyarakat membangun dengan material lokal dan material fabrikan dari dalam negeri, didapat dari toko terdekat.

Beberapa kriteria rumah hijau GBCI (2014) yang tidak dianalisis, dan dalam kategori tidak memenuhi antara lain:

- mengukur meter listrik hanya dari adanya meter listrik oleh PLN, tanpa sub meter listrik, karena daya listrik Rumah di Desa Kledung adalah 450 Watt, sehingga tidak diberi sub metering.

- penggunakan material pabrikan yang memikili system manajemen dalam produksi, dengan label tertentu, secara umum tidak menjadi prioritas masyarakat lereng gunung, karena masyarakat cenderung menggunakan material lokal (setempat) yang ada (Rejeki, 2015)

- Beberapa unsur terkait standar nasional secara terencana, tidak dilakukan oleh masyarakat pegunungan di rumahnya, seperti lampu (lux), kebisingan, sesuai standar SNI.

Selain itu ada kriteria yang dianalisis secara terbalik disebabhkan kondisi lingkungan yang bersifat dingin dan lembab, terutama terkait dengan memasukkan panas dan angin ke dalam bangunan yang dibutuhkan dalam masyarakat lereng gunung (Rejeki, 2018). Dalam kondisi ini, pada kawasan permukiman pegunungan dengan tinggi diatas $1.200 \mathrm{~m} \mathrm{dpl}$, memiliki kebutuhan kenyamanan untuk mengkondisian dalam ruang rumah, sedapat mungkin panas matahari (yang sebentar, pukul 07.00-12.00 jika udara cerah), sebanyak mungkin dimasukkan kedalam rumah. Selain itu dengan tingkat kemembaban tinggi (di atas 90\%) dan suhu lingkungan yang rendah, denderung ditahan tidak sampai masuk rumah. Dengan kondisi ini, unsur kenyamanan ruang diukur sesuai dengan kebutuhan.

Berdasar beberapa pengelompokan butir kriteria di atas, dapat disampaikan bahwa kriteria greensip Homes dalam GBCI (2014) yang dianalisis ada yang bersifat sama dengan pertimbangan adanya nilai sesuai pedoman, seperti disampaikan pada tabel 2.

Tabel 2. Tolok ukur penilaian sesuai standar

\begin{tabular}{|c|c|c|c|}
\hline \multirow[t]{2}{*}{ Uraian } & \multicolumn{3}{|c|}{ Tolok Ukur } \\
\hline & $\begin{array}{c}\text { Ada } \\
\text { besar } \\
\text { (nilai 3) }\end{array}$ & $\begin{array}{l}\text { Ada sedikit } \\
\text { (Nilai2) }\end{array}$ & $\begin{array}{c}\text { Tidak ada } \\
\text { (nilai 1) }\end{array}$ \\
\hline $\begin{array}{l}\text { Terdapat } \\
\text { Vegetasi }\end{array}$ & $>50 \%$ & $>30>50 \%$ & $<30 \%$ \\
\hline $\begin{array}{l}\text { Ada pohon } \\
\text { pelindung }\end{array}$ & $>1$ & 1 & Tidak ada \\
\hline $\begin{array}{l}\text { Jenis } \\
\text { Fasilitas }\end{array}$ & 10 fas & $5-9$ & $<5$ \\
\hline $\begin{array}{l}\text { Meter/ } \\
\text { pengukur air }\end{array}$ & 23.17 & 36.18 & 38.17 \\
\hline $\begin{array}{l}\text { Metering } \\
\text { listrik }\end{array}$ & Ada & ada & Tidak ada \\
\hline keberlanjutan & $\begin{array}{c}\text { Desain } \\
\text { berlanjut }\end{array}$ & $\begin{array}{l}\text { Material } \\
\text { berlanjut }\end{array}$ & Tidak ada \\
\hline $\begin{array}{l}\text { Penerangan } \\
\text { alami masuk } \\
\text { rumah }\end{array}$ & $>50 \%$ & Ada $<50 \%$ & Tidak ada \\
\hline $\begin{array}{l}\text { Lampu } \\
\text { hemat } \\
\text { energi }\end{array}$ & $\begin{array}{c}\text { Ada } \\
\text { semua }\end{array}$ & $\begin{array}{c}\text { Ada } \\
\text { bbrapa }\end{array}$ & $\begin{array}{l}\text { Tidak } \\
\text { ada }\end{array}$ \\
\hline $\begin{array}{l}\text { Persebaran } \\
\text { cahaya alami } \\
\text { masuk rumah }\end{array}$ & $\begin{array}{l}\text { Sebagian } \\
\text { besar }\end{array}$ & $50 \%$ ruang & $\begin{array}{l}\text { Sebagian } \\
\text { kecil }\end{array}$ \\
\hline $\begin{array}{l}\text { Alat } \\
\text { elektronik } \\
\text { hemat energi }\end{array}$ & $\begin{array}{c}\text { Ada } \\
>75 \%\end{array}$ & Ada $<75 \%$ & $\begin{array}{l}\text { Tidak } \\
\text { ada }\end{array}$ \\
\hline $\begin{array}{l}\text { Mengukur } \\
\text { meter listrik }\end{array}$ & $\begin{array}{c}\text { Ada } \\
>75 \%\end{array}$ & Ada $<75 \%$ & $\begin{array}{l}\text { Tidak } \\
\text { ada }\end{array}$ \\
\hline $\begin{array}{l}\text { Ada perhi- } \\
\text { tungan pema- } \\
\text { kaian listrik }\end{array}$ & $\begin{array}{l}\text { Ada } \\
\text { direnca- } \\
\text { nakan }\end{array}$ & $\begin{array}{c}\text { Ada } \\
\text { sekedar } \\
\text { dicatat }\end{array}$ & $\begin{array}{l}\text { Tidak } \\
\text { ada }\end{array}$ \\
\hline $\begin{array}{l}\text { Gunakan } \\
\text { material dapat } \\
\text { di terbarukan }\end{array}$ & $\begin{array}{c}\text { Banyak: } \\
\text { untuk } \\
\text { material } \\
\text { utama } \\
\text { dari/dapat } \\
\text { terbarukan }\end{array}$ & $\begin{array}{c}\text { Sedikit, } \\
\text { untuk } \\
\text { Material } \\
\text { pendukung } \\
\text { dari/dapat } \\
\text { terbarukan }\end{array}$ & $\begin{array}{l}\text { Tidak } \\
\text { Guna- } \\
\text { kan }\end{array}$ \\
\hline
\end{tabular}




\begin{tabular}{|c|c|c|c|}
\hline $\begin{array}{l}\text { Gunakan } \\
\text { material } \\
\text { bekas }\end{array}$ & $\begin{array}{l}\text { gunakan } \\
\text { untuk } \\
\text { material } \\
\text { utama }\end{array}$ & $\begin{array}{c}\text { gunakan } \\
\text { untuk } \\
\text { material } \\
\text { pendukung }\end{array}$ & $\begin{array}{l}\text { Tidak } \\
\text { guna- } \\
\text { kan }\end{array}$ \\
\hline $\begin{array}{l}\text { kurangi jejak } \\
\text { karbon }\end{array}$ & $\begin{array}{c}\text { Semua } \\
\text { material } \\
\text { lokal }\end{array}$ & $\begin{array}{c}\text { Sebagian } \\
\text { material } \\
\text { lokal }\end{array}$ & $\begin{array}{l}\text { Tidak ada } \\
\text { mat lokal }\end{array}$ \\
\hline & $>75 \%$ & $25-75 \%$ & \\
\hline $\begin{array}{l}\text { Ada furniture } \\
\text { daur ulang }\end{array}$ & $\begin{array}{c}\text { Ada } \\
\text { banyak } \\
>50 \%\end{array}$ & $\begin{array}{c}\text { Ada sedikit } \\
10-50 \%\end{array}$ & $\begin{array}{l}\text { Tidak } \\
\text { ada }\end{array}$ \\
\hline $\begin{array}{l}\text { Penggunaan } \\
\text { kayu legal/ } \\
\text { terdaftar }\end{array}$ & $\begin{array}{c}\text { Tidak } \\
\text { gunakan } \\
\text { kayu }\end{array}$ & $\begin{array}{c}\text { gunakan } \\
\text { sedikit/ } \\
\text { terdaftar }\end{array}$ & $\begin{array}{l}\text { Guna } \\
\text { kan } \\
\text { banyak } \\
\text { /tdk ter- } \\
\text { daftar }\end{array}$ \\
\hline $\begin{array}{l}\text { Penggunaan } \\
\text { material } \\
\text { interior } \\
\text { berbahaya }\end{array}$ & $\begin{array}{c}\text { Produk } \\
\text { yang } \\
\text { tidak } \\
\text { berpolut } \\
\text { an }>50 \%\end{array}$ & $\begin{array}{c}\text { Produk } \\
\text { polutan } \\
\text { sedikit } \\
10-50 \%\end{array}$ & $\begin{array}{l}\text { Produk } \\
\text { Berpo- } \\
\text { lutan }\end{array}$ \\
\hline $\begin{array}{l}\text { Kenyamanan } \\
\text { ruang gerak } \\
>9 \mathrm{~m} 2 \text { / orang }\end{array}$ & $\begin{array}{c}5-9 \\
\mathrm{~m} 2 / \text { orang }\end{array}$ & $\begin{array}{c}<5 \mathrm{~m} 2 / \\
\text { orang }\end{array}$ & Tidak ada \\
\hline $\begin{array}{l}\text { Dokumen } \\
\text { petunjuk } \\
\text { pemeliharaan }\end{array}$ & $\begin{array}{c}\text { Ada } \\
\text { dokumen }\end{array}$ & Ada lesan & Tidak ada \\
\hline $\begin{array}{l}\text { Aktifitas } \\
\text { ruang hijau }\end{array}$ & $\begin{array}{c}\text { banyak } \\
\text { tanaman } \\
\text { (ada } \\
\text { pohon } \\
\text { besar) }\end{array}$ & $\begin{array}{c}\text { Sedikit } \\
\text { tanaman } \\
\text { (ada pohon } \\
\text { perdu) }\end{array}$ & Tidak ada \\
\hline $\begin{array}{l}\text { Pemilahan } \\
\text { sampah }\end{array}$ & $\begin{array}{l}\text { Dipilah } \\
\text { Org - } \\
\text { anorg }\end{array}$ & $\begin{array}{c}\text { Sebagian } \\
\text { dipilah }\end{array}$ & $\begin{array}{r}\text { Tidak } \\
\text { dipilah }\end{array}$ \\
\hline $\begin{array}{l}\text { Aman dari } \\
\text { bencana }\end{array}$ & $\begin{array}{c}\text { Sadar } \\
\text { tanggap } \\
\text { bencana }\end{array}$ & $\begin{array}{c}\text { Sedikit } \\
\text { sadar/ } \\
\text { mengetahui } \\
\text { tanggap } \\
\text { bencana }\end{array}$ & $\begin{array}{l}\text { Tidak } \\
\text { Sadar/ } \\
\text { tidak tahu }\end{array}$ \\
\hline $\begin{array}{l}\text { Ada teknologi } \\
\text { berprinsip } \\
\text { green }\end{array}$ & $\begin{array}{c}\text { Ada } \\
\text { beberapa } \\
(>3) \\
\text { perabota } \\
n\end{array}$ & $\begin{array}{c}\text { Ada } \\
\text { Sedikit } \\
(1-3)\end{array}$ & Tidak ada \\
\hline $\begin{array}{l}\text { Dekat fasilitas } \\
\text { umum, } \\
\text { utilitas }\end{array}$ & Ada $>10$ & $>5$ & $<5$ \\
\hline $\begin{array}{ll}\text { Jarak } & \text { ke } \\
\text { transport } & \\
\text { umum } & \end{array}$ & $<500$ & $>500$ & Tidak ada \\
\hline $\begin{array}{l}\text { Penanggulang } \\
\text { an nyamuk, } \\
\text { lalat, tikus, } \\
\text { kecoan, rayap }\end{array}$ & $\begin{array}{l}\text { Semua } \\
\text { tidak ada }\end{array}$ & $\begin{array}{c}\text { Sebagian } \\
\text { penanggula } \\
\text { ngan ada }\end{array}$ & Semua ada \\
\hline $\begin{array}{l}\text { Pemanenan } \\
\text { air hujan atap }\end{array}$ & $\begin{array}{l}\mathrm{Ada}, \\
>500 \mathrm{~m}\end{array}$ & $\begin{array}{c}\text { Ada }>200 \\
m\end{array}$ & Tidak ada \\
\hline
\end{tabular}

\begin{tabular}{|c|c|c|c|}
\hline $\begin{array}{l}\text { Pemanenan } \\
\text { air hujan } \\
\text { halaman }\end{array}$ & $\begin{array}{c}\text { Ada } \\
\text { besar } \\
\text { (di bak } \\
\text { tampung) }\end{array}$ & $\begin{array}{l}\text { Ada kecil } \\
\text { (di ember/ } \\
\text { tong) }\end{array}$ & Tidak ada \\
\hline $\begin{array}{l}\text { Pemanfaatan } \\
\text { air hujan }\end{array}$ & $\begin{array}{l}\text { Dimanfa } \\
\text { atkan } \\
\text { untuk s/d } \\
\text { flushing } \\
\text { toilet }\end{array}$ & $\begin{array}{l}\text { Dimanfa- } \\
\text { atkan siram } \\
\text { tanaman }\end{array}$ & $\begin{array}{l}\text { Tidak ada } \\
\text { manfaat }\end{array}$ \\
\hline $\begin{array}{l}\text { Air siram } \\
\text { lamanan }\end{array}$ & $\begin{array}{c}\text { Tidak } \\
\text { gunakan } \\
\text { air } \\
\text { PDAM }\end{array}$ & $\begin{array}{l}\text { Gunakan } \\
\text { hemat } \\
\text { (secukupny } \\
\text { a mandi- } \\
\text { cuci) }\end{array}$ & $\begin{array}{l}\text { Gunakan } \\
\text { banyak (sd } \\
\text { unuk siram } \\
\text { tanaman) }\end{array}$ \\
\hline $\begin{array}{l}\text { Penggunaan } \\
\text { saptic tank } \\
\text { berjarak }\end{array}$ & $\begin{array}{l}\text { Jarak } 10 \\
\text { m dr } \\
\text { sumur/ } \\
\text { sb air }\end{array}$ & $\begin{array}{c}\text { Jarak }<10 \\
\text { meter dr } \\
\text { sumur/ sb } \\
\text { air }\end{array}$ & $\begin{array}{l}\text { Tidak ada } \\
\text { saptictank }\end{array}$ \\
\hline $\begin{array}{l}\text { Penggunaan } \\
\text { filter limbah } \\
\text { dapur }\end{array}$ & $\begin{array}{l}\text { ada, } \\
\text { selalu } \\
\text { difilter }\end{array}$ & $\begin{array}{c}\text { Ada, tidak } \\
\text { selalu } \\
\text { difilter }\end{array}$ & Tidak ada \\
\hline
\end{tabular}

Selain tolok ukur yang yang dibuat sesuai dengan kriteria dalam greenship homes rating tools (GBCI, 14), terdapat tolok ukur berdasar kriteria, tetapi keterangan pengukurannya tidak sesuai, karena keberadaan rumah tinggal ada di pegunungan bersuhu rendah dan kelembaban tinggi. Beberapa tolok ukur/ parameter yang digunakan secara spesifik pengukurannya antara lain terdapat pada tabel 3:

Tabel 3. Tolok ukur penilaian menyesuaikan lingkungan pegunungan (suhu dingin dan lembab).

\begin{tabular}{|c|c|c|c|}
\hline Uraian & & Tolok Ukur & \\
\hline $\begin{array}{l}\text { Bahan } \\
\text { material atap } \\
\text { sesuai lingk. }\end{array}$ & $\begin{array}{c}\text { Ada } \\
\text { Menyerap } \\
\text { panas }\end{array}$ & $\begin{array}{c}\text { Ada } \\
\text { menetralk } \\
\text { an }\end{array}$ & $\begin{array}{c}\text { Tidak ada } \\
\text { reduksi } \\
\text { panas }\end{array}$ \\
\hline $\begin{array}{ll}\text { System } & \\
\text { bukaan } & \text { untuk } \\
\text { angin/ } & \text { udara } \\
\text { masuk } & \end{array}$ & $\begin{array}{l}\text { Ada } \\
\text { bukaan } \\
1-5 \%\end{array}$ & $\begin{array}{c}\text { Ada } \\
\text { bukaan }> \\
5 \%\end{array}$ & $\begin{array}{l}\text { Tidak } \\
\text { ada } \\
\text { bukaan }\end{array}$ \\
\hline $\begin{array}{l}\text { Sirkulasi } \\
\text { angin di KM }\end{array}$ & $\begin{array}{l}\text { Ada } \\
\text { terbuka }\end{array}$ & $\begin{array}{l}\text { Ada } \\
\text { tertutup }\end{array}$ & $\begin{array}{c}\text { Tidak } \\
\text { ada }\end{array}$ \\
\hline
\end{tabular}

(2015)

Melalui penelitian yang dilakukan, dengan cara mengelompokkan kriteria, akan diketahui prinsip greenship homes yang bersifat umum, dapat diketahui bagian yang dapat diterapkan untuk menganalisis permukiman dalam kondisi khusus daerah pegunungan, dan diketahui bagian yang tidak dapat diterapkan, 
serta yang dapat diterapkan dengan tolok ukur disesuaikan.

\section{METODE}

Penelitian dilaksanakan melalui paradigma penelitian kualitatif naturalistik, dalam kondisi tidak ada rekayasa sutuasi lingkungan. Metode kualitatif digunakan dalam proses penggalian data dan analisis di lapangan. Kategori naturalistik dilakukan secara natural, alamiah, tanpa rekayasa situasi. Proses penelitian diawali penelusuran data, informasi primer dan penggalian data sekunder dilaksanakan secara kualitatif, langsung masuk ke lapangan untuk menelusur data fisik, wawancara informan dan data sekunder berupa dokumen tertulis, penelusuran dari jaringan web maupun jaringan internet lain. Proses analisis kategorisasi dilakukan sejak sebelum melakukan indept interview lapangan, yaitu berupa pengelompokan lokasi berdasar karakter kepadatan bangunan. Berikutnya hasil ditelaah lebih lanjut untuk memperoleh kategorisasi kecenderungan/ kemungkinan penerapan tolok ukur rumah hijau (greenship homes rating tools) di Desa Kledung. Secara keseluruhan metode penelitian ditempuh dalam tahap sebelum ke lapangan, selama di lapangan dan setelah di lapangan seperti tertuang dalam Gambar 4.

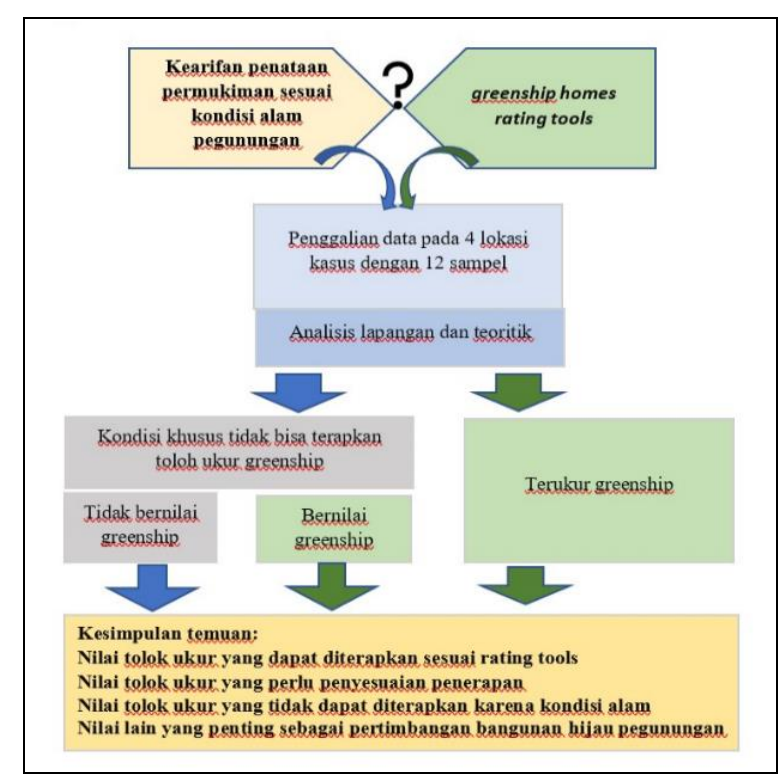

Gambar 4. Alur Proses Penelitian

\subsection{Penetapan Sampel Kasus}

Penetapan kasus didasari pertimbangan adanya kecenderungan persebaran rumah di Desa Kledung, yang memiliki keterkaitan pada hasil nilai kearifan rumah hijau di lingkungan masing-masing. Terdapat 4 kelompok karakter persebaran rumah di Desa Kledung, yaitu kelompok lingkungan dengan tatanan bangunan rumah padat baik di dekat jalan raya maupun yang ada di dalam permukiman, tatanan bangunan rumah sedang (agak renggang) dan tatanan bangunan saling berpencar. Kondisi ini digunakan untuk menetapkan sampel masing-masing (lihat Gambar 5).

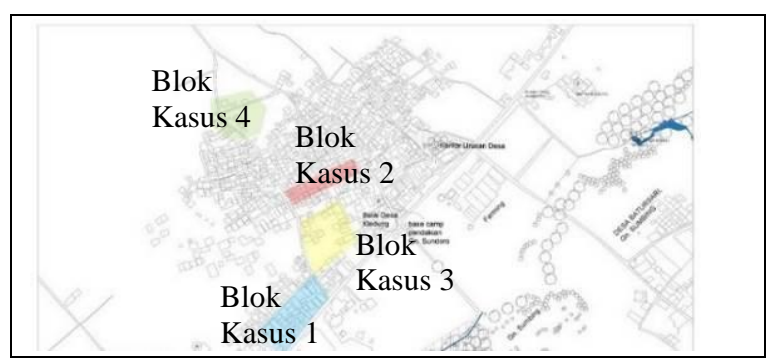

Gambar 5. Alur Proses Penelitian

Sampel kasus pada kelompok lingkungan blok kasus 1: padat rumah, berada pada jalan utama di Desa Kledung. Kondisi bangunan di lingkungan padat/ berderet, baik yang berada dekat dengan jalan raya maupun berada (lihat Gambar 6). Dari kasus ini, diambil data sebanyak 3 rumah, yang dapat mewakili karakter bangunan di desa Kledung. Dengan adanya penetapan kasus rumah secara purposive, pemilik rumah dijadikan sebagai informan penelitian, dengan nama disampaikan initial). Tiga rumah dimaksud terletak berderet, adalah rumah 1 milik bapak Srd, rumah 2 milik bapak Slm, dan rumah 3 milik ibu Nia (lihat Gambar 6). 


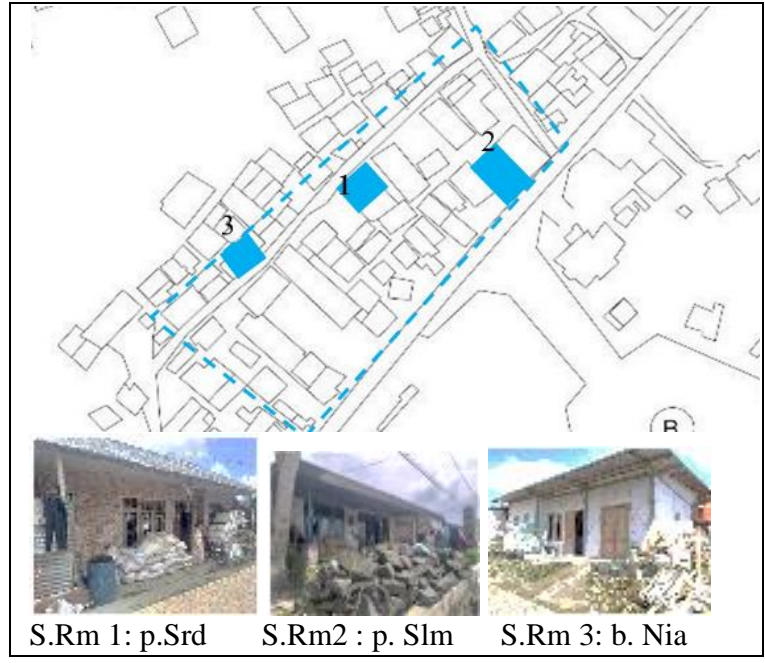

Gambar 6. Blok Kasus I lingkungan Padat/ Deret dekat jalan raya Temanggung Wonosobo

Sampel pada blok kasus 2, yaitu pada lingkungan di dalam permukiman yang padat, dimah berjajar, seperti terlihat pada Gambar 7.

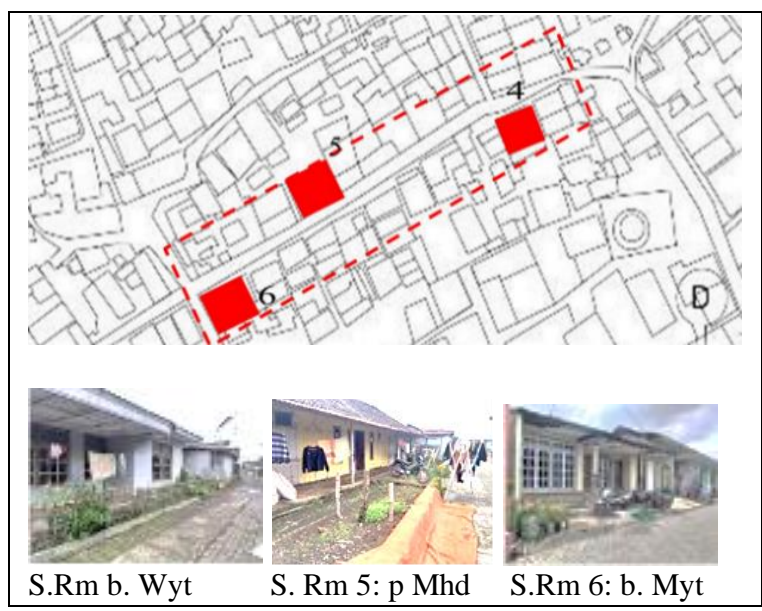

Gambar 7. Blok Kasus II lingkungan Padat/Deret

Pengabilan 3 sampel di kasus 2 ini dilakukan secara purposive, rumah yang mewakili karakter dan pemilik rumah dapat dijadikan sebagai informan. Ketiga sampel pada kasus 2 adalah (inisial) rumah milik ibu Wyt, rumah bapak Mhd dan rumah ibu Myt.

Sampel pada blok kasus III berada dilingkungan permukiman berkepadatan sedang (dalam 1 koridor jalan, jarak antar rumah agak renggang), Sampel yang ada di kelompok ini adalah sampel rumah 7 milik pak Adn, rumah 8 milik ibu Azh dan rumah 9 milik pak Nsd (lihat Gambar 8).

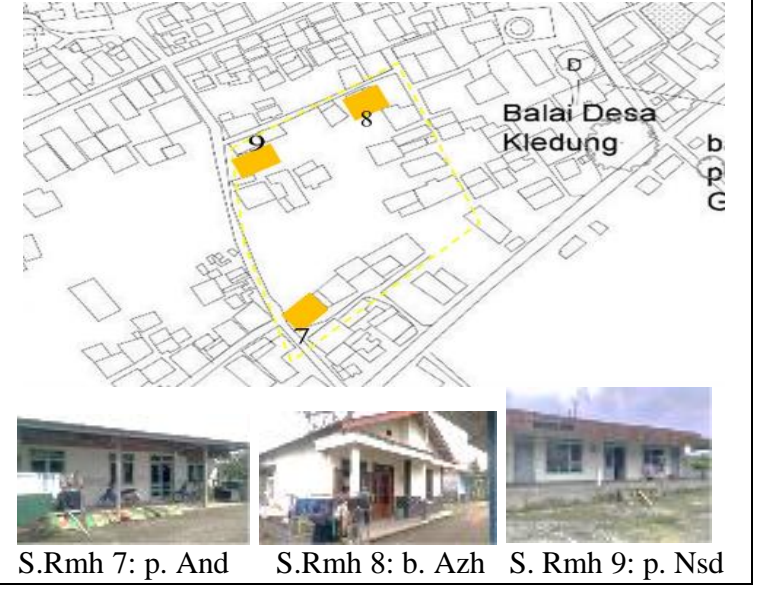

Gambar 8. Sampel Kasus III lingkungan Sedang/ Agak Renggang

Sample pada blok kasus IV, merupakan kelompok sampel di dalam lingkungan permukiman dengan jarak antara rumah renggang / terpencar. Blok sampel ini merupakan bentuk mpemekaran permukiman desai, yang mengarah/ mendekat ke kebun/ ladang. Sampel kasus pada blok kasus IV terdiri dari sampel rumah milik ibu Iv, rumah ibu Mrn dan rumah ibu Wwn (lihat Gambar 9)

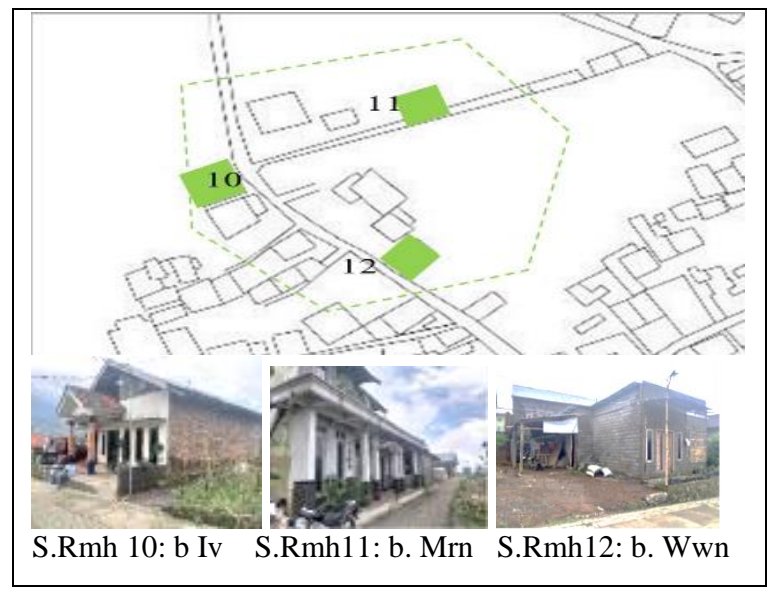

Gambar 9. Sampel Kasus IV Lingkungan Berpencar

\subsection{Metode Penelusuran Data}

Metode penelusuran data dilakukan secara kualitatif naturalistik dengan kerangka langkan dijabarkan sebelumnya, dilakukan berupa tahap menggali pengambilan data fisik dan non fisik bedasar data sekunder dan data primer. data sekunder berupa pengambilan foto udara dari Google Earth untuk Digambar ulang menjadi hambat peta Desa Kledung Kecamatan Kledung. Data primer dilakukan 
untuk menentukan sampel kasus (dengan cara menentukan langsung di lapangan, rumah yang sesuai dengan kelompok di maksud.

Seletah diperoleh sampel terpilih, pengambilan data primer berupa data seting fisik dengan pengambilan foto tampak, pembuatan sketsa rumah sesuai kriteria dan tolok ukur yang telah ditetapkan. Selain itu ada beberapa penggalian informasi secara lebih mendalam kepada pemilik rumah, terutama untuk menjawab beberapa hal yang bersifat keterangan (tidak ada bukti fisik) dan sekaligus penelusuran informasi alasan / pertimbangan diambil sikap tertentu.

\subsection{Metode Analisis}

Anilisis kualitatif dilakukan baik selama di lapangan (proses survei) maupun setelahnya. Proses analisis dilakukan untuk mengetahui nilai kearifan bangunan hijau yang terdapat di rumah tinggal di Desa Kledung baik yang merupakan prasyarat maupun yang memuat nilai. Analisis dilakukan karegorisasi sesuai kriteria, pada masing-masing rumah setiap kelompok sampel, setelahnya dilakukan interkoneksi temuan, sehingga diperoleh keteranyaman temuan, yang dikerucutkan menjadi temuan lokal tentang kearifan sikap peduli terhadap lingkungan yang sinergi, dapat terkonversi terhadap ketetapan rumah hijau (greenship homes) secara umum.

Tahap berikutnya hasil temuan yang diperoleh didialogkan terhadap prinsip greenship homes rating tools menurut GBCI yang bersifat umum, untuk dapat difahami bagian mana yang tidak dapat digunakan untuk permukiman lereng gunung, bagian mana yang dapat diterapkan, dan ada bagian tertentu yang perlu penyesuaian.

\section{HASIL DAN PEMBAHASAN}

Penelitian dilakukan pada 12 sampel yang ditetapkan untuk mewakili 4 karakter lingkungan rumah (padat dekat jalan raya, padat di dalam permukiman, agak renggang dan renggang/ terpencar. Setelah dilakukan penggalian diperoleh informasi bahwa tidak terdapat keragaman yang mendasar pada keempat karakter lokasi, sehingga dalam proses analisis dilakukan dalam satu kesatuan. Berdasar informasi data dan analisis diperoleh temuan bahwa untuk menerapkan prinsip rumah hijau menurut GBCI ada yang dapat diukur nilai secara langsung, ada yang perlu penyesuaian indikator/ tolok ukur karena kondisi klimatik lingkungan di lereng gunung dan ada kriteria yang tidak dapat dijadikan pengukuran, baik yang bernilai positif (bangunan hijau) maupun yang bersifat negatif.

\subsection{Nilai kearifan terhadap prasyarat rumah hijau}

Terdapat enam (6) kriteria prasyarat rumah hijau menurut GBCI. Masing-masing prasyarat dapat dilihat dari karakter bangunan yang ada. secara keseluruhan prasyarat letak bangunan di desa Kledung (prasyarat 1) menempati satu zonasi (mengelompok), walaupun ada yang berada di zona cukup padat maupun yang renggang bahkan terpencar sebagai bentuk proses pertumbuhan rumah mangarah ke atas (kebun). Oleh keberadaan dalam 1 cluster permukiman, dapat dikategorikan keberadaan sesuai (dominasi nilai 3). Dilihat dari seting tata bangunan terhadap masing-masing kapling, di setiap bangunan mengandalkan tanah sekitarnya untuk peresapan air apa adanya (prasarat 2), tanpa membuat resapan khusus (dominasi nilai 2). Keberadaan listrik di desa Kledung (prasarat 3) sudah terdapat di semua rumah, dengan pengukuran meter listrik yang dipasangoleh PLN, masyarakat menerima apa adanya (nilai 2 dan 3). Untuk Prasyarat 4, yaitu pengendalian Ozon oleh keberadaan AC tidak menjadi permasalahan karena di permukiman ini tidak ada yang menggunakan AC (lingkungan sudah sangat dingin, nilai 3). Untuk kriteria prasarat ke 5 penggunaan material non asbestos, di Kawasan desa Kledung ada komdinasi penggunakan atap seng, genting dan ditemukan asbes. Sebagian besar menggunakan material bukan asbes atau ada asbes sedikit, tetapi ada beberapa bangunan (2 dari 12 sampel) yang menggunakan asbes, dengan pertimbangan harga murah. Kriteria ke 5, pemilahan sampah, di desa Kledung terdapat program masyarakat untuk memilah sampah, terutama sampah anorganik spt plastik, walau pelaksanaannya ada yang pelaksanaan seadanya (nilai 2-3). Secara keseluruhan pemenuhan prasyarat 
rumah hijau dapat dilihat pada tabel 4 , dengan simpulan bahwa pada dasarnya permukiman di daerah gunung (dingin lembab), memiliki kearifan mengkondisikan lingkungannya sesuai dengan kondisi alam dan memenuhi kaidah konsep bangunan hijau. Dengan kata lain, konsep prasyarat bangunan hijau tidak terlepas dengan kearifan bangunan di Kawasan lereng gunung/ pegunungan.

Tabel 4. Kearifan setempat terhadap nilai prasarat

\begin{tabular}{|c|c|}
\hline Uraian & Hasil \\
\hline \multirow[t]{4}{*}{$\begin{array}{l}\text { Kesesuaian } \\
\text { fungsi }\end{array}$} & $\begin{array}{l}\text { I : berada di mayoritas hunian dan } \\
\text { campur lain (di jalan raya) }\end{array}$ \\
\hline & $\begin{array}{c}\text { II : berada di lingkungan permukiman } \\
\text { dan campuran (olah tembakau) }\end{array}$ \\
\hline & $\begin{array}{l}\text { III : berada di lingkungan mayoritas } \\
\text { hunian dan campur (olah } \\
\text { tembakau) }\end{array}$ \\
\hline & $\begin{array}{c}\text { IV : berada di mayoritas hunian dan } \\
\text { campur lain (olah tembakau) }\end{array}$ \\
\hline \multirow[t]{4}{*}{$\begin{array}{l}\text { Resapan/ } \\
\mathrm{KDH}\end{array}$} & $\begin{array}{l}\text { I : langsung jalan dan ada sedikit } \\
\text { pekarangan (kurang sesuai) }\end{array}$ \\
\hline & $\begin{array}{l}\text { II : langsung jalan dengan sedikit } \\
\text { halaman depan teras (kurang } \\
\text { sesuai) }\end{array}$ \\
\hline & $\begin{array}{l}\text { III : langsung jalan dengan sedikit } \\
\text { halaman depan teras (kurang } \\
\text { sesuai) }\end{array}$ \\
\hline & $\begin{array}{l}\text { IV : langsung dan agak mudnur dar } \\
\text { jalan, ada halaman depan dan } \\
\text { samping bangunan (sesuai) }\end{array}$ \\
\hline Meter listrik & $\begin{array}{l}\text { Semua menggunakan meter listrik } \\
\text { masing-masing, dipasang oleh PLN, } \\
\text { sesuai. }\end{array}$ \\
\hline Pasif energi & $\begin{array}{l}\text { Semua bangunan tidk menggunakan } \\
\text { AC, sesuai dengan kondisi Kawasan } \\
\text { gunung sudah dingin dan kearifan } \\
\text { sesuai lingkungan alam. Nilai kearifan } \\
\text { maksimal. }\end{array}$ \\
\hline \multirow[t]{4}{*}{ material } & $\begin{array}{l}\text { I : material dominasi bahan seng dan } \\
\text { genting, sedikit yang }\end{array}$ \\
\hline & $\begin{array}{c}\text { II : ada yang menggunakan material } \\
\text { asbes, ada yang material lain }\end{array}$ \\
\hline & $\begin{array}{l}\text { III : penggunaan Material dominasi } \\
\text { material lain, ada sedikit } \\
\text { menggunakan asbes }\end{array}$ \\
\hline & $\begin{array}{l}\text { IV : campur penggunaan material lain } \\
\text { dan asbes }\end{array}$ \\
\hline $\begin{array}{l}\text { Pengelolaan } \\
\text { sampah }\end{array}$ & $\begin{array}{l}\text { Semua memilah sampah organik dan } \\
\text { anorganik, terutama plastik, untuk } \\
\text { sampah organik ada yang dimasukkan } \\
\text { lubang untuk menjadi pupuk dan ada } \\
\text { yang diambil tukang sampah. }\end{array}$ \\
\hline
\end{tabular}

Dari hasil di atas terlihat bahwa dari 6 prasyarat utama, ketentuan bangunan rumah hijau (greenship homes), ada 1 prasyarat yang pasti terlaksana oleh penyesuaian kondisi klimatik di daerah ketinggian gunung, yaitu pasif energi, dan ada 2 prasyarat yang berlangsung baik di desa Kledung terdukung oleh adanya system kerja PLN (pemasangan meter), dan adanya program desa tentang pemilahan sampah. Kearifan sikap terhadap prasyarat yang lain bersifat vasiasi. Untuk kearifan ternadap prasyarat kesesuaian terhadap zona Kawasan, memenuhi karena memang sistem permukiman pedesaan sifatnya mengelompok pada suatu tempat, sedang di sekelilingnya baru berupa ladang, sawah maupun kebun. Kemungkinan penyimpangan terjadi pada waktu ada pembangunan yang bersifat terpencar, sebagai awal pertumbuhan desa. Prasyarat tentang ruang terbuka hijau, untuk masing-masing bangunan tidak memperlihatkan adanya banyak ruang hijau, dengan peritimbangan kearifan ruang-ruang sekitar bangunan digunakan untuk menjemur tembakau paska panen (lihat gambar 10), selain itu, pemahaman resapan air oleh tanah, masuk banyak di luar Kawasan permukiman. Temuan ini merupakan tipe / karakter permukiman ladang lereng gunung yang tinggi, seperti disampaikan Santosa (2019) dan Rejeki (2010) terkait ketergantungan masyarakat peladang terhadap alam lingkungan baik selama sebelum panen maupun paska panen.

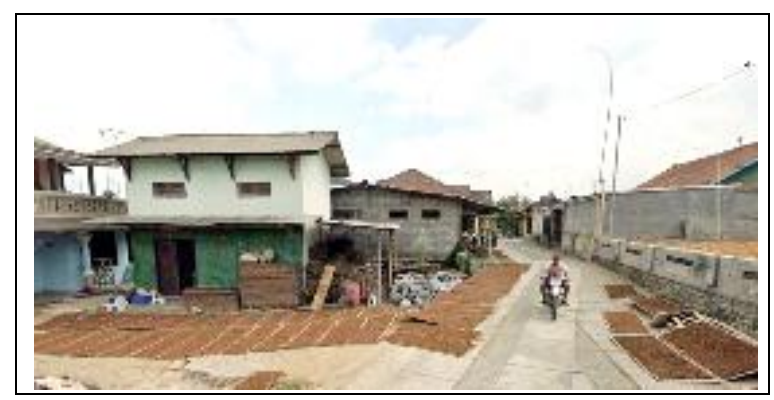

Gambar 10. Kondisi Lingkungan Permukiman Minim Ruang Hijau untuk jemur tembakau.

Prasyarat lain terkait material, di Kawasan desa Kledung terdapat beberapa rumah warga yang menggunakan asbestor, walaupun dominasi atap di desa ini menggunakan atap seng dan genteng. Pertimbangan penggunaan atap asbes karena murah, Dominasi penggunaan atap seng dengan pertimbangan mampu menyerap panas untuk dimasukkan ke bangunan (Rejeki, 2010). 
Secara keseluruhan, dari keenam prasyarat yang ada, yang paling sulit untuk dipenuhi keberadaan nya adalah di dalam kapling/ persil rumah diberi penghijauan, karena kebutuhan panas lingkungan guna menjemur tembakau. Adanya beberapa rumah yang memiliki halaman juga tidak ditanami dengan penghijauan. Untuk prasyarat yang lain masih dapat secara alamiah dilaksanakan oleh warga berupa kearifan setempat,walau tanpa harus diatur, tetapi sudah sinergi dengan standar bangunan hijau.

\subsection{Nilai kearifan khusus berdasar keberadaan di Kawasan gunung}

Secara lebih terukur, terkait dengan butir kriteria bangunan hijau, dilihat dari kearifan nilai oleh masyarakat dalam menata lingkungan dan huniannya, ada yang tidak dapat menerapkan secara penuh sesuai ketetapan di dalam rating tools GBCI, antara lain tentang pemilihan bahan bangunan, sistem bukaan dan sirkulasi angin.

Kondisi lingkungan di Kawasan pegunungan, terutama yang memiliki ketinggian di atas 1.000 meter, suhu rendah dan kelembaban tinggi (Rejeki, 2010), sehingga adanya tiupan angih kecil sudah memberikan rasa dingin pasa tubuh manusia. Untuk memperoleh kenyamanan terutama selama berada di dalam rumah sebagai alat perlindungan diri dari cuaca, secara arif masyarakat memiliki strategi penanganan terkait bahan dan sistem bukaan yang khusus. Secara umum, material yang sesuai untuk menyerap panas dan dimasukkan ke dalam bangunan. Hasil penelusuran di Desa Kledung, terdapat rumah yang menggunakan seng, genteng dan Sebagian kecil asbes. Selain itu, di bagian dalam diberi plafond, sehingga panas tidak langsung masuk ke dalam bangunan. Hasil ini memperlihatkan bahwa rumah di desa Kledung netral, tidak secara khusus memasukkan panas ke dalam bangunan, tetapi juga tidak mengalihkan panas. Hal ini terjadi baik di bagian atap maupun bagian dinding bangunan.

Dilihat dari sistem bukaan dan sirkulasi angin, secara prinsip pada Kawasan yang memiliki kelembaban tinggi, tidak terlalu banyak memiliki bukaan, apalagi sirkulasi antar ruang , karena adanya tiupan angin akan memberikan rasa dingin yang lebih tinggi (Rejeki, 2010). Rumah-rumah di Desa Kledung (sampel penelitian), semua ada bukaan, tetapi dominasi kurang dari $5 \%$, dan beberapa sampai $5 \%$, berupa pintu dan jendela, serta bouven dari kaca mati. Keberadaan bukaan ini tidak selalu dibuka, sehingga tidak semua selalu ada sirkulasi cross ventilasi, terkecuali bukaan centilasi udara dari kamar mandi dominasi ada bukaan. Hal ini menunjukkan, di desa ini, dengan kondisi iklim luar bangunan yang lembab dan dingin, tetap ada kemungkinan sirkulasi udara, tetapi dimanfaatkan sepertunya (tabel 5). Menurut keterangan informan memilik rumah, apabila udara dingin, dapat menutup pintu atau jendela.

Tabel 5. Kearifan setempat terhadap prasarat

\begin{tabular}{|c|c|}
\hline Uraian & Hasil \\
\hline $\begin{array}{l}\text { Material } \\
\text { Atap }\end{array}$ & $\begin{array}{l}\text { Pemilihan material atap bersifat neral, } \\
\text { ada yang mengunakan genteng, asbers } \\
\text { dan seng. Penggunaan atap seng tidak } \\
\text { selalu dimantfaatkan } \\
\text { memasukkan panas, oleh adanya } \\
\text { plafond }\end{array}$ \\
\hline $\begin{array}{l}\text { Material } \\
\text { Dinding } \\
\text { dan Lantai }\end{array}$ & $\begin{array}{l}\text { Pemilihan material dinding dengan } \\
\text { batu bata, batako. Bersifat netral, } \\
\text { lantai ada yang menggunakan ubin dan } \\
\text { keramik. Penggunaan keramik } \\
\text { menyebabkan lantai menjadi dingin. }\end{array}$ \\
\hline Bukaan & $\begin{array}{l}\text { Semua rumah ada bukaan berupa } \\
\text { pintu dan jendela, berkisar antara 1-5 } \\
\% \text { dan ada beberapa yang lebih. } \\
\text { Bukaan ini sifatnya tidak selalu } \\
\text { terbuka, apabila situasi sedang dingin, } \\
\text { jendela dan pintu ditutup. }\end{array}$ \\
\hline $\begin{array}{l}\text { Sirkulasi } \\
\text { angin KM }\end{array}$ & $\begin{array}{l}\text { Sebagian besar (11 sampel) memiliki } \\
\text { bukaan sirkuias udara dri KM, } \\
\text { sehingga udara dapat mengalir keluar. }\end{array}$ \\
\hline
\end{tabular}

\subsection{Nilai kearifan rumah hijau yang dapat diterapkan secara umum.}

Sebelum mengupas lebih jauh kearifan masyaratat desa Kledung dalam menyikapi rumah dan lingkungan nya terhadap nilai rumah hijau, disampaikan dalam website Kabupaten Temangung 2012, lingkungan permukiman di desa Kledung yang berada pada ketinggian sekitar 1.138 meter dpl. Kondisi suhu udara lingkungan desa aini rata-rata dingin, yaitu terdingin $18^{\circ} \mathrm{C}$ dan paling panas $29^{\circ} \mathrm{C}$. Desa ini tidak terlalu sering hujan tetapi sering berkabut, dengan rata-rata hari hujan hanya 64 hari dalam 1 tahun. Sinar matahari 
menerangi desa ini setiap hari rata-rata pukuk 07.00-12.00, sedangkan waktu lain berupa terang langit dan berkabut. Dengan kondisi ini, penerapan / peninjauan nilai rumah hijau (greenship homes) tidak dapat secara penuh digunakan.

Tidak banyaknya pohon peneduh di lingkungan ini (Gambar 11), bahkan disekitar permukiman, karena di daerah ini memang tidak terlalu memerlukan peneduh, sementara lahan yang ada digunakan untuk kebun / ladang tembakau dan sayuran yang memerlukan panas matahari.

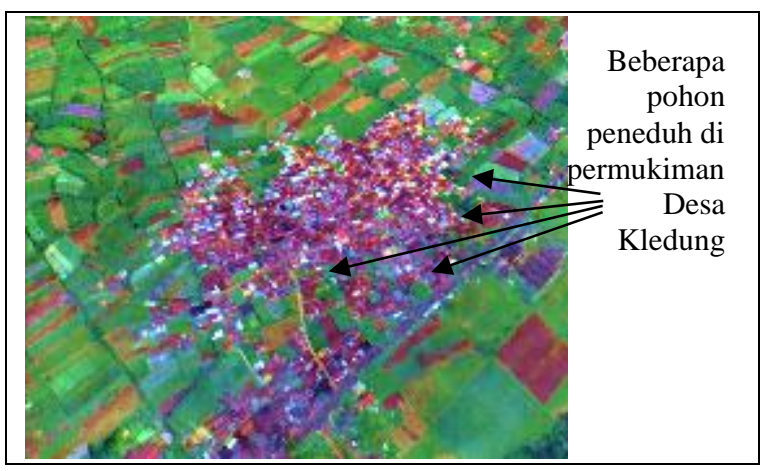

Gambar 11. Klaster Permukiman Desa Kledung dengan beberapa peneduh

Sumber: Google Earth, diakses 10 Maret 2021

Kondisi di dalam lingkungan permukiman dengan kondisi tidak ada tanaman peneduh karena juga dibutuhkan untuk pendukung mata pencaharian yaitu menjemur tembakau, seperti terlihat pada Gambar 12.

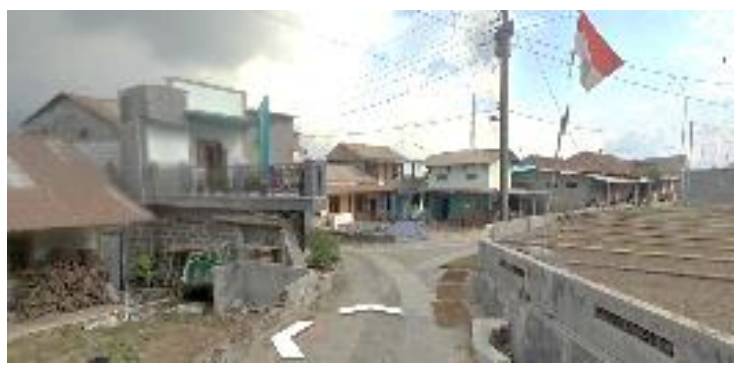

Gambar 12. Lingkungan Desa Kledung tanpa pohon peneduh

Sumber: Google Earth, diakses 10 Maret 2021

Berdasar kearifan penataan lingkungan di atas, dilakukan analisis kondisi terhadap nilai-nilai bangunan rumah hijau dengan hasil beberapa nilai green yang dapat diterapkan dan dihitung antara lain menyangkut keberadaan tamanan penghias lokal, pemantauan penggunaan listrik, dan

Tabel 6. Kearifan setempat terhadap nilai prasarat

\begin{tabular}{ll}
\hline Uraian & \multicolumn{1}{c}{ Hasil } \\
\cline { 2 - 2 } Kebera & - Ada nya tanaman hias di teras sekitar 30- \\
daan & $50 \%$ dari di kasus I dan II, dan di kasus III \\
vegetasi & dan IV berkisan ada yang < 30\% jenis \\
& tanaman hias (sekedar ada), dan yang \\
& ditanam adalah tanaman lokal.
\end{tabular}

Luas Kenyamanan ruang semua sampel ruang memenuhi karena bangunan semua besar nyaman sehingga setiap orang $>9 \mathrm{~m}^{2}$

Petunju Ada rekam jejak pada semua sampel, $\mathrm{k} \quad$ Petunjuk pemeliharaan dan kondisi pelihara bangunan disampaikan sederhana oleh -an tukang yang membangun, tanpa dokumen tertulis

Penggu - material dominan material lokal

naan - penggunaan material terbaruhan banyak

material yang menggunakan material bekas milik sendiri, milik orang tua (tidak mengadakan/ membeli khusus)

- penggunaan material furniture terbarukan sekedar yang dimiliki dari orang tua, tidak mengadakan furniture dari barang daur ulang

- beberapa memanfaatkan zeng untuk memasukkan panas, ada yang genting dan ada asbes

Kebera - hunian (rumah) berada pada 1 kelompok, daan dengan fasilitas berkisar 5-10 fasilitas yang rumah berdekatan

- Sarana transportasi dari jalan raya, sehingga selain rumah kasus I yang dekat jalan raya, jetaknya lebih dari $500 \mathrm{~m}$.

Keberada Rata-rata ada jarak, hanya tidak an WC diperhatihakn ukuran, keamana didapat aman dari pembuatan kedalaman saptictank.

Peneran - Sebagian besar rumah memiliki bukaan gan sehingga sinar atahari mampu menerangi alami lebih dari 50\% dari luar suang

Penggu - Terdapat meter listrik utama, sekedar ada naan oleh PLN

listrik - Terdapat pengukuran listrik secara sederhana berupa pemantauan pembayaran bulanan,

Penghe - Penggunaan listrik sederhana (hanya matan lampu dan TV, pemanas air dan penanak listrik nasi (tanpa kulkas dan AC)

dan - Penggunaan elektronik hemat listrik ada, energi sesuai dengan keterangan pada produk (produk hemat energi). 
Kenya Tidak ada penggunaan AC, sehingga manan- penvemaran zat udara oleh AC tidak ada. kesehat Pencemaran ozon

an

Aktifit - Aktifitas yang menyiratkan kegiatan as bertanam Sebagian besar sampel berupa harian tanama rambat, hanya pada kasus -4 sampel berspi 11 tidak ada aktifitas penanaman.

bangu - Pemilahan sampah terdapat pada semua nan sampel, didukung program desa. Ada yang hijau sepenuhnya, ada yang sekedar memilah

- Pengelolaan linmbah dapur berupa saringan terdapat pada 2 lokasi ( 5 sampel), sedang Sebagian besar tidak dilakukan pemilahan limbah dapur

- Penyiraman tanamah Sebagian besar mengunakan air sumur / air hujan, terdapat pada semua lokasi, hanya 3 sampel yang menggunakan air bersih PDAM (tidak emiliki sumur). Dan 3 sampel menggunakan air hujan yang ditampung.

- Penangguklangan hama dilakukan terhadap tukus dan lalat, dilakukan oleh 4 sampel di lokasi 1 dan lokasi 3.

Oleh banyaknya hal yang dapat dilakukan analisis terhadap nilai bangunan rumah hijau, memperlihatkan bahwa pada dasarnya kondisi bangunan dan lingkungan di Kawasan lereng gunung, kasus di Desa Kledung, secara arif tertata dengan nilai-nilai bangunan hijau berspirit berkelanjutan.

Selain beberapa hal yang dapat diperhitungkan, sesuai dengan penjelasan sebelumnya, terdapat beberapa hal yang tidak dapat diperhitungkan karena keberadaannya di lereng gunung, terdiri dari keberadaan pohon pelindung yang tidak dibutuhkan (bahkan mengganggu kebutuhan sinat matahari), proses membangun oleh masyarakat (vernakular) dan pemanfaatan air gunung yang melimpah. (Tabel 7). Ketiga kondisi ini tidak memungkinkan untuk diukur dengan kriteria dan tolok ukur bangunan hijau GBCI, karena potensi dan kebutuhan aktifitas yang spesifik.
Tabel 7. Kritera bangunan rumah hijau yang tidak terdapat di Desa Kledung

\begin{tabular}{lll}
\hline Uraian & \multicolumn{3}{c}{ Hasil } \\
\cline { 2 - 3 } Vegetasi & $\begin{array}{l}\text { Tidak adanya pohon pelindung pada } \\
\text { setiap rumah, disebabkan akrena } \\
\text { kebutuhan untuk jemur hasil panen dan } \\
\text { kondisi lingkungan sering berkabur/ } \\
\text { terang langit. }\end{array}$ \\
$\begin{array}{l}\text { Proses } \\
\text { memba- } \\
\text { ngun }\end{array}$ & $\begin{array}{l}\text { Semua tidak didampingi Tenaha ahli, } \\
\text { maksimal ahli adalah tukang. }\end{array}$ \\
$\begin{array}{l}\text { Kebutuhan } \\
\text { air }\end{array}$ & $\begin{array}{l}\text { Penggunaan air sumur melimpat } \\
\text { menyebabkan tidak dilakukan } \\
\text { pengukuran pemanfatan air. }\end{array}$ \\
\hline
\end{tabular}

\section{KESIMPULAN}

Berdasar analisis dan pembahasan terhadap 12 sampel yang pewakili 4 karakter kasus lokasi hunian di Desa Kledung, dapat disimpulkan bahwa pada dasarnya adanya kearifan tata permukiman di daerah pegunungan yang menyikapi kondisi spesifik alam gunung, secara prinsip kontekstual dapat dinilai sebagai bangunan rumah hijau kawasan gunung/ pegunungan.

Beberapa karakter khusus yang memberikan spesifikasi tolak ukur khusus menyangkut ketidakbutuhan terhadap 1) pohon peneduh, oleh kebutuhan panas matahari untuk proses paska panen tembakau, 2) terhadap potensi air gunung yan berlebih sehingga tidak perlu melakukan penghematan (tanpa berhemat air gunung masih sisa terbuang), 3) budaya masyarakat bergotong royong secara vernakular dalam membangun rumah, tanpa ahli khusus selain tukang.

Kearifan penataan permukiman yang dapat dinilai sebagai bangunan rumah hijau meliputi banyak hal, antara lain: 1) bangunan rumah luas, sehingga rasio penghuni melebihi tolok ukur, 2) pengadaan meter listrik, pemantauan operasional listrik dipantau secara sederhana, 3) aktifitas berbasis bangunan hijau dilaksanakan walau secara sederhana seperti menanggulangan hama, pemilahan sampah, 4) pemanfaatan bahan lokal dan bahan bekas selama ada, 5) pemanfaatan cahaya matahari masuk rumah, 6) pengelolaan angin selama dibutuhkan.

Secara keseluruhan, prinsip bangunan hijau (greenship homes) dapat diterapkan pada 
Kawasan tertentu (untuk penelitian ini kasus di daerah pegunungan), dengan mempertimbangkan spesifikasi kondisi setempat ( kriteria bangunan hijau tidak serta merta dapat diterapkan). Beberapa konsisi khusus terkait seting dan kondisi klimatik setempat menjadi pertimbangan.

\section{UCAPAN TERIMAKASIH}

Pada kesempatan ini diucapkan terima kasih terhadap kampus Unika Soegijapranata, khsuusnya Fakultas Arsitektur dan Desain yang telah memberikan kesempatan dosen melakukan penelitian bersama mahasiswa, yang dapat dimanfaatkan bersama bagi pribadi dosen maupun masing-masing perkuliahan dan penelitian mahasiswa. Ucapan banyak terima kasih juga disampaikan kepada bapak Bopo dan warga Desa Kledung yang telah menerima dan memberikan informasi yang dibutuhkan selama penelitian.

\section{REFERENSI}

Azizah, Ronim; Wardani, Eny Dwi; Mardikasari, Awita Aryani (2017), Pengukuran Greenship Homes Pada Rumah Tinggal Berkonsep 'Green'" di Perkotaan, Jurnal Teknik Sipil dan Perencanaan 19 (1), 17-24. Diakses 15 Desember 2020.

Dianaty, Putri Savira (2018), Penerapan Green Building Pada Rumah Tinggal Berdasarkan Greenship Rating Tools Di Komplek Perumahan Kota Banda Aceh Dan Kabupaten Aceh Besar, Fakultas Teknik Universitas Syariah Kuala, Banda Aceh. Diakses https://etd.unsyiah.ac.id/baca/index.php?i $\mathrm{d}=45891$ \&page $=1$, tanggal 10 Februari 2021

Direktorat Pengembanan Perangkat Penilaian GBCI (2014), GreenshipRating Tools untuk Rumah Tinggal Greenship Homes Version 1.0, Jakarta.

Hilmidya, Nicholas; Rejeki, VG Sri; Mulyani, IM Tri Hesti (2014), Rumah Tinggal di Desa Kapencar dikaji Dengan The Gaia House Charter, Progam Paska Sarjana, Univ. Katolik Soegijapranata, Semarang.

Latuconsina, Maudi Bay Tazya (2018), Evaluasi Konsep Bangunan Hijau pada
Bangunan Rusunawa Pesakih di Jakarta Barat, Fakultas Teknik Universitas Brawijaya, Malang: 101

Pambudi, Bagus, 2014), Analisis Kesesuaian Desain Rumah Terhadap Konsep Greenship Home Pada Perumahan Menengah Ke Atas, Jurnal Rekayasa Teknik Sipil1 (1). Diakses 15 Des 2020.

Rejeki,VG Sri; Suwarno, Nindyo; Suraryono; Subroto, Yoyok T.W, Putra, Heddy Sri Ahimsha (2010) Prinsip Keruangan Bagi Petani Ladang Tbmbakau Di Lingkungan Desa Kapencar, Lereng Gunung Sindoro, Wonosobo, Jurnal Manusia Dan Lingkungan, 17 (1): 46-56.

Rejeki, VG Sri; Pradipto (2010), Pengaruh Iklim Lokal Terhadap Bahan Bangunan Rumah Tinggal di Desa-desa Lereng Gunung, Jurnal Tesa Arsitektur 8 (2): 8495.

Rejeki, VG Sri (2015) Strategi Rekayasa Bangunan Rumah Tinggal di Pegunungan bersuhu dingin Kasus Desa Kapencar Wonosobo, Tesa Arsitektur 15 (1): 26-30

Rejeki, VG Sri; Indrajati, Yovita (2015), Community's Wisdom in the Process of Building Houses According to the Nature of Slope of Mountain, Jurnal International Journal of Chemical, Environtmental and Biological Csience (IJCEB) 3(4): 258-262

Rejeki, VG Sri; Kiswari, MD Nestri; Saraswati, Ratih Dian (2018), Penerapan Konsep Rumah Tinggal Hijau Greenship Homespada Tipe Rumah Tinggal Terencana di SemarangKasus Rumah Tinggal Lahan Luas dan Rumah Tinggal Lahan Sempit, Proseding Temu IPLBI-7, Semarang: F114-F121.

Santosa, Dian Kartika; Antariksa; Utami, Sri 2019 Tipologi Rumah Ladang di Desa Enclave Taman Nasional Bromo Tengger Semeru, Ngadas, kabupaten Malang, $\begin{array}{lll}\text { Jurnal Arsitektura } 17 & \text { (2):271-282. }\end{array}$ Diakses 15 Desember 2020

Wahyu U.S, Russiana; Wahyuwibowo, Agung Kumoro; Nirawati, Maya Andria (2019), Penerapan Kajian Arsitektur Hijau dalam Strategi Perancangan Terminal Bus dan Pusat Perbelanjaan di Kabupaten Karanganyar, Jurnal Arsitektura 17 (2): 203-210. Diakses 15 Des 2020. 
Yanta, Fikri (2019), Persepsi penerapan aspek Manajemen Lingkungan Bangunan pada Perumahan di Dusun TGK. Tanoh Abee kota Banda Aceh diakses tanggal $10 \mathrm{Feb}$ 2021.

https://etd.unsyiah.ac.id/baca/index.php?i $\mathrm{d}=55891 \&$ page $=1$ 